\title{
URGENSI BUDAYA LITERASI DAN UPAYA MENUMBUHKAN MINAT BACA
}

\author{
Mulasih $^{1}$, Winda Dwi Hudhana ${ }^{2}$ \\ Universitas Peradaban $^{1}$ \\ Universitas Muhammadiyah Tangerang ${ }^{2}$ \\ Mulasih.tary@gmail.com ${ }^{1}$ \\ windhana89@gmail.com ${ }^{2}$
}

\begin{abstract}
ABSTRAK
Literasi di Indonesia mengalami ketertinggalan dibandingkan negara-negara maju. Indonesia menduduki peringkat ke-64 dari 65 negara pada tahun 2012. Hal tersebut sangat memprihatinkan, mengingat negara Indonesia merupakan negara dengan penduduk yang sangat banyak. Faktor yang mempengaruhi budaya literasi terkait dengan faktor intern dan extern. Faktor intern berkaitan dengan individu personal dan faktor extern berkaitan dengan lingkungan persoal. Masyarakat Indonesia seharusnya menyadari pentingnya membaca, karena mambaca mampu menghadirkan pengetahuan yang tidak terbatas. Kebiasaan membaca seharusnya dipupuk sejak dini. Kebiasaan membaca sejak dini ternyata dapat menggali bakat dan potensi anak. Membaca juga memacu daya nalar dan melatih konsentrasi. Para orang tua seharusnya mampu memberikan motivasi agar anak-anak gemar membaca. Selain itu, pemerintah juga diharapkan menyediakan perpustakaan yang ramah dengan anak. Perpustakaan ramah anak mempunyai ciri-ciri yaitu 1) suasana interior yang disukai anak, 2) koleksi buku dan CD yang mendukung kegiatan anak, 3) pelayanan yang menyenangkan untuk anak, dan 4) melakukan kegiatan anak misalnya mendongeng.
\end{abstract}

Kata kunci: Budaya Literasi, Minat Baca

\section{A. PENDAHULUAN}

Beberapa penelitian mengenai budaya literasi beberapa tahun lampau membuktikan bahwa budaya literasi di Indonesia sangat rendah.Menurut UNESCO bahwa budaya literasi bangsa Indonesia menempati urutan ke 60 dari 61 negara di dunia. Selain itu, menurut data dari UNESCO bahwa budaya literasi di Indonesia hanya mencapai 1\% yang menyukai kegiatan membaca dan 99\% tidak menyukai kegiatan membaca. Budaya literasi di masyarakat khususnya di kalangan anak-anak masih minim, masih banyak anak yang hanya membaca satu buku bahkan tidak sama sekali dalam satu bulan bahkan dalam satu tahun.

Faktor penyebab rendahnya budaya literasi dikalangan masyarakat Indonesia sangat banyak. Faktor tersebut dibedakan menjadi faktor intern individu dan ekstern individu. Faktor intern individu yaitu tidak memiliki waktu luang, lebih menyenangkan gatged daripada buku, tidak tertarik pada buku, masih minimnya kesadaran pentingnya literasi, dan sebagainya.Sedangkan faktor ekstern individu yaitu fasilitas buku yang kurang memadahi, harga buku relatif mahal, 
Lingua Rima: Jurnal Pendidikan Bahasa dan Sastra Indonesia

Vol. 9 No. 2 Juli 2020

tidak ada dukungan dari orang tua, tidak adanya kebiasaan membaca di lingkungan sekitar, dan sebagainya.

Budaya literasi perlu adanya pembiasaan dan kesadaran di lingkungan masyarakat.Para orang tua seharusnya mampu membimbing anak-anaknya sejak dini untuk gemar membaca. Usia anak dini merupakan usia emas yang mana masa tersebut merupakan masa para anak memiliki ingatan panjang. Usia dini adalah kesempatan emas anak dalam mempelajari sesuatu atau dapat disebut dengan golden age (Sulistyani, 2015:14). Anak pada usia ini memiliki ketertarikan yang sangat pada lingkungan.

Menurut Locke bahwa manusia berkembang sesuai dengan tempramen masing-masing individu dan lingkungan yang mempengaruhi pembentukan pemikiran seseorang (Khotimah, 2015:62). Proses perkembangan seorang anak sebenarnya terjadi dalam masa bayi yang mana pada masa itu, bayi dapat dibentuk dan dipengaruhi sesuai keinginan orang tua dan lingkungan sekitar. Apabila seorang anak yang dibesakan dalam keluarga dan lingkungan yang gemar membaca, maka dengan sendirinya anak tersebut terbentuk menjadi generasi yang menjunjung tinggi gerakan literasi. Untuk itu, anak usia dini sangat tepat apabila orang tua mampu menerapkan gerakan literasi di lingkungan keluarga maupun sekitar.

\section{B. MENINGKATKAN MINAT BACA}

Menurut hasil survey oleh Internasional Association for Evaluation menyebutkan bahwa keterampilan membaca siswa SD di Indonesia berada pada urutan ke-29 dari 30 negara. Rendahnya minat baca juga terlihat dari catatan UNESCO yang menunjukkan bahwa indeks minat baca mencapai 0,001 artinya dari 1000 orang hanya satu orang yang suka membaca (sumber Republikan.co.id 11 November 2014 dalam Nafisah, 2014:710). Padahal minat baca yang tinggi mempengaruhi kualitas pendidikan, apabila siswa memiliki minta baca tinggi maka kualitas pendidikan pasti tinggi. Oleh karena itu, perlu adanya membangkitkan minat baca peserta didik.

Di Negara maju seperti Jepang, gerakan membaca telah dirintis sejak 30 tahun lalu.Jepang memberlakukan gerakan membaca 20 menit untuk ibu dan anak.Dalam gerakan ini seorang ibu dianjurkan membacakan buku 20 menit untuk anaknya yang bisa dipinjam dariperpustakaan umum.Tak diragukan lagi, kemajuan yang dicapai Jepang pada saat ini merupakan buah dari kerja keras pemerintah Jepang untuk membangun budaya literasi yang dimulai sejak dari anakanak (Shofaussamawati, 2014:50). 
Lingua Rima: Jurnal Pendidikan Bahasa dan Sastra Indonesia

Vol. 9 No. 2 Juli 2020

Di Belanda, pemerintahnya sangat serius dalam usaha menumbuhkan minat baca di kalangan anak-anak. Membaca dan menulis sudah merupakan gaya hidup dan dimulai sejak usia dini. Walaupun anakanak kecil belum bisa membaca, pembacaan dongeng atau cerita sebelum tidur, adalah salah satu ritual penting bagi hampir seluruh anak Belanda. Pemerintah Belanda bekerja sama dengan perpustakaan, taman bermain, taman kanak-kanak dan sekolah dasar, menyelenggarakan sejumlah kegiatan gemar membaca yang berlangsung regular (Shofaussamawati, 2014:50).

Salah satu negara tetangga yaitu Australia, menumbuhkan minat bacanya masyarakatnya dengan menjadikan anak-anak sebagai sasaran utama.Sejak warganya masih bayi, Pemerintah Australia sudah memperkenalkan dengan buku, caranya setiap ibu yang melahirkan mendapatkan kunjungan dari lembaga kesehatan pemerintah untuk melihat kondisi ibu dan membawakan buku pertama bayi.Buku tersebut 51 dibuat berdasarkan penelitian, sehingga sangat berguna untuk bayi(Shofaussamawati, 2014:51)

Di South Australia dan Victoria, pemerintah daerah menyelenggarakan Premier's Reading Challenge atau Tantangan Membaca dari Premier (Kepala Pemerintahan Tertinggi).Kegiatan ini ternyata sangat berdampak positif bagi anak-anak.Setiap hari anak-anak meminjam buku yang berbeda dari sekolahnya untuk dibaca malam harinya.Dan yang menarik, mereka membaca tanpa paksaan.asacinta. blogspot.com Departemen Pendidikan dan sekolah di Australia menumbuhkan minat baca sejak anak-anak belum bisa membaca. Sekolah menerapkan Reading Journal, yaitu catatan harian masing-masing anak tentang buku apa yang telah dibacanya setiap hari. Catatan tersebut akan diperiksa oleh guru pada akhir bulan dan anak yang berhasil membaca 25 buku dalam sebulan akan mendapatkan penghargaan. Penghargaan yang dimaksud bukan berupa materi, hanya sebuah stiker kecil bertuliskan "25 Night Reading Certifi cate" yang ditandatangani sang guru. Penghargaan sederhana ini sudah sangat membuat anak-anak gembira dan semangat untuk membaca (Shofaussamawati, 2014:51).

Tidak sedikit orang sukes yang berasal dari keluarga yang cinta membaca. Karena itu, pentingnya oangtua mengapresiasikan budaya baca pada anak dengan memberi contoh.Orangtua dapat menumbuhkan minat baca pada anak dengan rajin mendongeng dan memperkenalkan buku-buku cerita yang disesuaikan usianya.Yang perlu diingat, jangan mendorong anak untuk membaca sementara orangtuanya tidak pernah membaca.Karena mencontohkan lebih efektif ketimbang bicara (Shofaussamawati, 2014:51). 
Lingua Rima: Jurnal Pendidikan Bahasa dan Sastra Indonesia

Vol. 9 No. 2 Juli 2020

\section{MENINGKATKAN MINAT BACA MELALUI PERPUSTAKAAN}

Penyediaan perpustakaan untuk anak-anak yang ramah anak merupakan salah satu upaya meningkatkan minat baca. Perpustakaan anak dirasa dapat menjadi investasi jangka panjang untuk meningkatkan minat baca. Anak-anak cenderung suka bermain, maka rubahlah perpustakaan menjadi sarana bermain anak. Salah satunya dengan menempatkan beberapa wahana permainan dan buku-buku sehingga anak-anak tidak hanya fokus membaca, namun mereka juga dapat bermain. Hal tersebut dilakukan dengan tujuan agar anak dapat betah di perpustakaan.

Menurut (Shofaussamawati, 2014:56-57) di Surabaya, tepatnya di Jalan Mayjen Sungkono, terdapat perpustakaan anak yang merupakan cabang dari Perpustakaan Wilayah Propinsi Jawa Timur, yang didirikan khusus untuk anak-anak. Fasilitas yang dibangun meliputi ruang koleksi, ruang baca, ruang bermain, ruang mendongeng, ruang audiovisual, ruang komputer, konter sirkulasi, lobby dan fasilitas pendukung lainnya. Konsep yang digunakan dalam perancangan adalah 'taman bermain'. Menilik dari berbagai contoh perpustakaan anak tersebut diatas, ada beberapa hal yang penting untuk diperhatikan dalam menciptakan perpustakaan anak ataupun perpustakaan umum ramah anak, antara lain:

1. Suasana interior. Anak-anak pasti menyukai ruang perpustakaan yang cerah dengan dinding berwarna terang, ditambah foto atau lukisan yang menarik di dindingnya. Ruang baca sebaiknya tidak terlihat gelap dan pengap aroma buku. Sirkulasi udara yang baik dan pencahayaan yang cukup penting untuk menciptakan ruangan yang nyaman, sekaligus sebagai langkah perawatan buku agar tidak mudah rusak karena udara lembab.Untuk membangun perpustakaan seperti ini tidak harus mewah.

2. Koleksi buku dan $\mathrm{CD}$ audio visual. Persoalan koleksi buku menjadi sorotan utama pengguna layanan perpustakaan. Tentu saja tidak hanya masalah jumlah yang harus diperbanyak, perpustakaan juga harus mampu menjadi penyedia sekaligus filter dengan menyediakan buku-buku bermutu saja.

3. Pelayanan perpustakaan. Keceriaan anak-anak seringkali menyebabkan suasana gaduh dalam ruang perpustakaan.Untuk mengatasi hal ini, perlu ditempatkan petugas perpustakaan yang sabar dan mampu memberi penjelasan kepada anak-anak tentang peraturan perpustakaan. Pustakawan harus mengerti bagaimana memperlakukan anakanak dengan ramah, dan membantu kesulitan mereka dalam mencari koleksi buku yang 
Lingua Rima: Jurnal Pendidikan Bahasa dan Sastra Indonesia

Vol. 9 No. 2 Juli 2020

diinginkan. Anak-anak yang masih relatif baru dengan berkenalan dengan perpustakaan tentu akan semangat meminjam buku. Semangat ini hendaknya didukung dengan penerapan system peminjaman yang mudah bagi mereka.

4. Mendengarkan Cerita. Anak-anak memang masih terbatas kapasitasnya dalam membaca. Karena itu diperlukan bantuan orang dewasa untuk membacakan buku cerita. Pembacaan cerita atau story telling adalah kegiatan yang umum dilakukan di perpustakaanperpustakaan ramah anak.Dengan kegiatan ini, tidak ada batasan bagi anak yang belum bisa membaca sekalipun untuk dapat mengkonsumsi buku bacaan.Storytelling dapat dilakukan secara berkala seminggu sekali atau dua kali dengan jam dan tempat yang telah diinformasikan kepada umum. Anak mana yang menolak menyimak storytelling?

\section{DAFTAR PUSTAKA}

Khotimah, Khusnul. 2015. Peran Orang Tua dalam Mengembangkan Perilaku Sosial pada Anak Usia Dini. Jurnal Insania Jurnal Pendidikan. Fakultas Tarbiyah dan Ilmu Keguaran.Institut Agama Islam Negeri Purwokerto. Vol 20 No 1 Januari-Juni 2015 PP 59-78

Nafisah, Aliyatin. 2014. Arti Penting Perpustakaan bagi Upaya Peningkatan Minat Baca Masyarakat. Jurnal Libraria. STAIN Kudus. Vol 2 No 2 Th 2014

Shofaussamawati. 2014. Menumbuhkan Minat Baca dengan Pengenalan Perpustakaan pada Anak Sejak Dini. Jurnal Libraria. STAIN Kudus. Vol 2 No 1 Th 2014

Sulistyani, Anggraeni Mashinta. 2015. Pengenalan Sains bagi Anak Usia Dini Menggunakan Metode Permainan. Jurnal Insania: Jurnal Pendidikan. Fakultas Tarbiyah dan Ilmu Keguaran.Institut Agama Islam Negeri Purwokerto. Vol 20 No 1 Januari-Juni 2015 PP 1327 